\title{
Temporal and spatial variation in metric asymmetry in skulls of polar bears (Ursus maritimus) from East Greenland and Svalbard
}

\author{
Thea $\varnothing$. Bechshøft' ${ }^{1,2}, \varnothing y s t e i n ~ W_{i i g}{ }^{1}$, Christian Sonne ${ }^{2, *}$, Frank F. Rigét ${ }^{2}$, \\ Rune Dietz ${ }^{2}$, Robert J. Letcher ${ }^{3}$ \& Derek C. G. Muir ${ }^{4}$
}

1) Natural History Museum, University of Oslo, P.O. Box 1172 Blindern, N-0562 Oslo, Norway

2) Department of Arctic Environment, National Environmental Research Institute, University of Aarhus, P.O. Box 358, DK-4000 Roskilde, Denmark ( ${ }^{*}$ corresponding author's: csh@dmu.dk)

3) National Wildlife Research Centre, Science and Technology Branch, Environment Canada, Carleton University (Raven Road), Ottawa, ON, Canada K1A OH3

4) National Water Research Institute, Environment Canada, Burlington, Ontario, Canada L7R 4A6

Received 26 Apr. 2007, revised version received 12 Nov. 2007, accepted 6 Nov. 2007

Bechshøft, T. Ø., Wiig, Ø., Sonne, C., Rigét, F. F., Dietz, R., Letcher, R. J. \& Muir, D. C. G. 2008 : Temporal and spatial variation in metric asymmetry in skulls of polar bears (Ursus maritimus) from East Greenland and Svalbard. - Ann. Zool. Fennici 45: 15-31.

Fluctuating asymmetry (FA) as a measure of environmental stress was studied in polar bear (Ursus maritimus) skulls from East Greenland ( $n=300$, collected 1892-2004) and Svalbard ( $n=391$, collected 1950-2004). Nine metric traits in skull and lower jaw were measured. FA levels of each trait were compared between sex/age groups (subadults, adult females, adult males), periods ( $\leq 1960,>1960)$, and localities (East Greenland, Svalbard). The period $\leq 1960$ was chosen to represent a period prior to the appearance of organohalogen pollution in the Arctic. Results indicated that Svalbard bears generally had a higher level of FA than those of East Greenland. Overall, no substantial evidence of a linkage between FA and organohalogens was found. Instead, indications were of subpopulations with declining levels of FA over time, suggesting the existence of positive population level effects powerful enough to overrule the influence of stress caused by global warming, pollution, and overharvesting.

\section{Introduction}

Fluctuating asymmetry (FA) refers to small, random deviations from the ideal morphological symmetry and is typically measured as the absolute difference between a trait on the left- and the right-hand side of a bilaterally symmetrical organism (Møller \& Swaddle 1997, Palmer \& Strobeck 2003a). Generally, one must presume that the two sides of the same individual develop according to the same genetic programme and are exposed to identical influences from the extrinsic environmental factors, such as temperature, noise, food access and quality, chemicals, parasites, and diseases (e.g. Siegel \& Mooney 1987, Borisov et al. 1997, Stige 2004, Jones et al. 2005, Møller 2006, Petavy et al. 2006). FA is often taken as a measure of developmental stability (DS), "the ability to attain equal development under the given circumstances" (Zakharov 
1992), and its counterpart developmental instability (DI). In principle, DS reflects the organism's ability to buffer its development against disturbance (Møller \& Swaddle 1997). The more fit the genotype of an organism, and the less stress from the surrounding environment it is exposed to, the higher DS and thus lower FA it is expected to have (Stige 2004). FA is therefore often taken as an indicator of phenotypic and genotypic quality (Møller \& Swaddle 1997). As such, it can be used as a helpful tool in population dynamics research, where FA measurements could potentially be used as a substitute for, or as a supplement to, the more traditional ways of estimating the condition and fitness of a population (Clarke 1995, Baranov et al. 1997, Zakharov et al. 1997a, Stige 2004). High levels of FA have been connected with inbreeding depression (Baranov et al. 1997), high population density (Zakharov et al. 1997b), and genetic factors such as increased levels of hybridization and heterozygosity (Borrell et al. 2004, Andersen et al. 2006). Studies of FA have been conducted on metric and meristic traits of a multitude of organisms (plants: Pelabon et al. 2006, arthropods: Lajus \& Alekseev 2004, Vilisics et al. 2005, Andersen et al. 2006, fish: Jagoe \& Haines 1985, Green \& Lochmann 2006, mammals; Zakharov \& Yablokov 1990, Pertoldi et al. 2003).

An organism's DS is often believed to be largely determined during the foetal stage (e.g. Siegel et al. 1977b, Møller \& Swaddle 1997, Valetsky et al. 1997). However, aspects such as canalization (Nijhout \& Davidowitz 2003) and plasticity (Nijhout \& Davidowitz 2003, Palmer \& Strobeck 2003a) are also important concerns. A robust methodology is essential in FA studies to avoid serious flaws in the analyses (e.g. Merilä \& Björklund 1995, Stige 2004). One of the greatest challenges in working with FA is getting the measurement error (ME) as small as possible (e.g. Merilä \& Björklund 1995, Palmer \& Strobeck 2003a, Stige 2004). In order to quantify ME in relation to FA it is important to take replicate and independent measurements (Palmer 1994, Merilä \& Björklund 1995, Palmer $\&$ Strobeck 2003a). The obtained measurements must also be examined for directional asymmetry (DA) and anti-symmetry, as such measurements are presumed to be a result of other factors than a low DS (Palmer \& Strobeck 2003a, Stige 2004).

Many studies have been conducted in order to identify which forms of stress can affect FA and DS. Factors such as social stress (Valetsky et al. 1997, Gibbs \& Breuker 2006), inbreeding (Pertoldi et al. 2000a), sexual selection (Voigt et al. 2005), nutritional stress (Pravosudov \& Kitaysky 2006), heat stress (Siegel et al. 1977a, Petavy et al. 2006), and disease and parasitic stress (Møller 2006) have been found to be positively correlated with levels of FA. Organic pollution is one form of environmental stress that has been another positively correlated with FA (e.g. Zakharov \& Yablokov 1990, Borisov et al. 1997, Zakharov et al. 1997a, Maul \& Farris 2005). The Arctic acts as a sink for a range of persistent organic pollutants (POPs), most of them organohalogens (OHCs) such as polychlorinated biphenyls (PCBs), chlordane (CHL), dichlorodiphenyltrichloroethane (DDT), dieldrin, hexachlorocyclohexane $(\mathrm{HCH})$, hexachlorobenzene (HCB), and polybrominated diphenyl ethers (PBDEs) (AMAP 2004). Many of these pollutants are highly lipophilic and bio-accumulate in marine food chains, particularly in the fatty tissue of marine mammals (e.g. Borgå et al. 2001, AMAP 2004, Muir et al. 2006). Because the polar bear is an Arctic top predator, whose diet mainly consists of blubber from ringed seals (Phoca hispida) and bearded seals (Erignathus barbatus) (Ramsay \& Stirling 1988, Derocher et al. 2002), it has indeed been found to carry some of the highest POP loads of any Arctic mammal species, especially so in bears from Svalbard and East Greenland (Norstrom et al 1998, Dietz et al. 2004, Verreault et al. 2005, Muir et al. 2006, Dietz et al. 2007, Gebbink et al. 2008). Chronic exposure to these pollutants in the polar bears has been associated with afflictions such as endocrine disruption, reduced size of sexual organs and bone mineral density, and organ histopathology (e.g. Wiig et al. 1998, Derocher et al. 2003, Braathen et al. 2004, Lie et al. 2004, Sonne et al. 2004, Kirkegaard et al. 2005, Sonne et al. 2005a, 2005b, Sonne et al. 2006a, 2006b).

The use and outputs of for example PCBs, one of the major organochlorines, began in the 1950s and peaked in the 1960s (AMAP 2004, Dietz et al. 2004). Reports on the temporal trends of the persistent organic pollutants in 
the Arctic now show indications of a decline in several of the "older" toxic substances over the last decades (e.g. Derocher et al. 2003, Dietz et al. 2004, Verreault et al. 2005, Riget 2005), while many novel contaminants seem to increase (Corsolini et al. 2002, Bossi et al. 2005, Muir et al. 2006, Smithwick et al. 2006). The potential adverse health effects from this organohalogen cocktail are unknown and make for a complex pattern when attempting to link organohalogen pollutants with FA.

Sonne et al. (2005a) investigated FA in a sample of polar bears from East Greenland and found no relation between pollution loads and FA. This present study is different from the aforementioned one in that the measuring equipment used is electronic and more exact, meaning lower ME and thus, supposedly, more robust results. Also, all traits were measured twice, and more robust statistical methods were applied than those reported in Sonne et al. (2005a), to obtain a more robust estimation of ME. In addition, the present investigation included polar bears from the Svalbard subpopulation, thus enabling a more extensive and comparative study with the added geographical element. The overall aim of the present study was to study metric FA in a combined sample of skulls of East Greenland and Svalbard polar bears in order to obtain information about spatial and temporal trends in the effects of environmental stress on DS.

\section{Materials and methods}

\section{Samples}

A sample of 300 polar bear skulls from East Greenland (held at the Zoological Museum, University of Copenhagen), and 391 polar bear skulls from Svalbard (held at the Natural History Museum, University of Oslo) were examined (Table 1). The skulls were collected in 1892-2004 (East Greenland, app. $61^{\circ}-82^{\circ} \mathrm{N}$, $10^{\circ}-42^{\circ} \mathrm{W}$ ) and 1950-2004 (Svalbard, app. $\left.74^{\circ}-81^{\circ} \mathrm{N}, 10^{\circ}-35^{\circ} \mathrm{E}\right)$. Many of the skulls were more or less damaged, and thus the entire range of measurements could not be performed on all skulls. The age determination of the skulls had been done by counting the cementum Growth
Layer Groups (GLG) of the lower right incisor (I3) after decalcification, thin sectioning (14 Am) and staining (Toluidine Blue), using the method described by Hensel and Sorensen (1980) and Dietz et al. (1991). The age of 271 skulls from East Greenland and 227 skulls from Svalbard had been determined. Individuals were categorised as subadults (S), adult females (F) and adult males (M) as follows: Adult males $\geq 6$ years old, adult females $\geq 5$ years old and the remaining as subadults (Rosing-Asvid et al. 2002). Skulls were classified into the periods $\leq 1960$ and $>1960$ according to year of birth (age subtracted from year of kill). Measurements of individual levels of PCBs, HCB, HCHs, DDTs, dieldrin, CHLs, and PBDEs in subcutaneous adipose tissue were available from a subsample of 65 of the bears from East Greenland. Further details on the levels of the organohalogen compounds in relation to season, sex, and age are given in Dietz et al. (2004, 2007), Sandala et al. (2004), and Muir et al. (2006).

Table 1. Number of skulls of polar bears (Ursus maritimus) from East Greenland and Svalbard used in analyses of fluctuating asymmetry of the present study.

\begin{tabular}{|c|c|c|}
\hline & East Greenland & Svalbard \\
\hline Bears measured in total & 300 & 391 \\
\hline Subadult & $\begin{array}{c}133 \\
\left(68 \text { \%, } 580^{7}\right)\end{array}$ & $\begin{array}{c}131 \\
\left(51 \stackrel{9}{\circ}, 650^{7}\right)\end{array}$ \\
\hline Adult female ( $\geq 5$ years) & 59 & 89 \\
\hline Adult male ( $\geq 6$ years) & 73 & 111 \\
\hline \multicolumn{3}{|c|}{ Bears of known age (and hence year of birth) } \\
\hline Subadult & 133 & 98 \\
\hline Adult female & 59 & 60 \\
\hline Adult male & 73 & 63 \\
\hline \multicolumn{3}{|l|}{ Bears born $\leq 1960$} \\
\hline Subadult & 40 & 9 \\
\hline Adult female & 24 & 43 \\
\hline Adult male & 49 & 58 \\
\hline \multicolumn{3}{|l|}{ Bears born > 1960} \\
\hline Subadult & 93 & 101 \\
\hline Adult female & 35 & 10 \\
\hline Adult male & 24 & 13 \\
\hline \multicolumn{3}{|l|}{ Bears born $\geq 1950$} \\
\hline Subadult & 98 & 89 \\
\hline Adult female & 44 & 49 \\
\hline Adult male & 36 & 55 \\
\hline \multicolumn{3}{|c|}{ Bears with available contaminant data and age } \\
\hline Subadult & 36 & 0 \\
\hline Adult female & 18 & 0 \\
\hline Adult male & 11 & 0 \\
\hline
\end{tabular}




\section{Measurements}

Nine metric bilateral traits were measured in order to estimate the level of FA in the skulls (Table 2 and Fig. 1). Each trait was measured on the right $(R)$ and left $(L)$ side of each skull, using digital callipers (Mitutoyo, Mitutoyo Corporation, Japan) to the nearest $0.04 \mathrm{~mm}$. The traits were measured twice on each skull, always by the same person, and never twice on the same day.

\section{Identification of sex}

The Svalbard subadult sample consisted of 131 individuals, of which 90 were of known sex (52 male, 38 female). The adult sample consisted of 235 individuals, of which 137 were of known sex ( 84 male, 53 female). In the East Greenland sample, 88 of the 133 subadults were of known sex (47 male, 41 female), and 132 of the 133 adults were of known sex (73 male, 59 female). Classificatory analyses (see below) were run on the three groups with a larger number of individuals of undetermined sex (Svalbard: Subadult and adult, East Greenland: Subadult) (Hair et al. 2006). This was done in order to reach a higher number of individuals $(n)$ with known sex and thus more degrees of freedom (df) in later analyses. The first of the repeated measurements (right side of all traits) were used as depend- ent variables when assessing normality for the bears of known sex in each subgroup. Males and females were handled separately. Normality was assessed by applying the Shapiro-Wilk test solely to the bears of known sex with valid values in all dependent variable categories, as these were the bears which would be used in the further classificatory analyses. Factor analysis with a principal components extraction, stepwise binary logistic regression, and stepwise discriminant analyses were run in order to obtain suggestions for different models to discriminate between males and females. These analyses helped in understanding which variables (traits) were of greater importance when looking to discriminate between the sexes. The variables (traits) of least importance could thus be sorted out, and the analyses run again. The fewer the variables applied in each analysis, the higher the number of individuals $(n)$ included in the calculation of the model would be. The higher $n$ would cause the remaining variables to better meet the normality distribution.

Simultaneous discriminant analyses were used to analyze the various suggestions for a model, and the best solution for this study (a combination of high percentage of individuals with known sex correctly identified and a high number of individuals with unknown sex identified) was chosen. The resulting classifications were applied to the data set and used in further analyses.

Table 2. Definition of the nine metric traits measured on skulls of East Greenland and Svalbard polar bears (Ursus maritimus).

\begin{tabular}{|c|c|}
\hline Trait & Definition \\
\hline \multicolumn{2}{|l|}{ Skull } \\
\hline OPF & Maximal distance between the opistokranion and the postorbital process of the frontal bone. \\
\hline CBL & $\begin{array}{l}\text { Condylobasal length. The maximal distance between the anterior margin of the alveole of the } 1 \text { st } \\
\text { incisor and the anterior margin of the occipital condyles. }\end{array}$ \\
\hline $\mathrm{P} 4-\mathrm{M} 2$ & Length from the anterior margin of the 4th premolar to the posterior margin of the 2nd molar. \\
\hline C-M2 & Length from the anterior of the alveole of the canine, to the posterior of the alveole of the 2 nd molar. \\
\hline $\mathrm{I} 1-\mathrm{M} 2$ & $\begin{array}{l}\text { Length from the anterior of the alveole of the } 1 \text { st incisor, to the posterior of the alveole of the } 2 \text { nd } \\
\text { molar. }\end{array}$ \\
\hline $\mathrm{POH}$ & $\begin{array}{l}\text { Postorbital height. The minimal distance between the postorbital process of the frontal bone and the } \\
\text { frontal process of the zygomatic arch. }\end{array}$ \\
\hline \multicolumn{2}{|c|}{ Lower jaw } \\
\hline Lp4 & Length of the 4th premolar of the lower jaw. \\
\hline ML & $\begin{array}{l}\text { Mandible length. The maximal distance between the anterior margin of the mandibular symphysis } \\
\text { and the posterior margin of the angular process. }\end{array}$ \\
\hline $\mathrm{MH}$ & $\begin{array}{l}\text { Mandible height. The maximal distance between the margin of the angular process and the } \\
\text { coronoid process. }\end{array}$ \\
\hline
\end{tabular}




\section{Statistical analyses}

\section{Preliminary examination of data}

All traits were tested with regards to normality, anti-symmetry, size dependency, and directional asymmetry (DA). Traits OPF, C-M2, I1-M2, $\mathrm{POH}$ and Lp4 all exhibited ideal FA. Significant DA was discovered in two traits, P4-M2 ( $p$ $<0.0001)$ and ML $(p<0.0001)$. If deviations from symmetry are heritable in traits that exhibit DA, then apparent differences in DS among groups could arise solely due to differences in the amount of inherited variation for asymmetry (Palmer 1994). In other words, DA goes against the theoretic "common ground" of FA, the ability of individuals in a given group to attain equal development under the given circumstances. In order to check the influence of DA on FA, analyses on traits P4-M2 and ML were also carried out using the absolute value of the residuals of a regression of the left and right side traits instead of simply $(|R-L|)$ as the dependent variable (Pertoldi et al. 2000b). Only two results changed when using the residuals instead of the general FA-index: In the three-way ANOVA estimating FA within periods, locations and sex/age groups (see below), $\mathrm{ML}_{\text {(Resid.) }}$ was not significant in any interactions (Table 3), but in the main factor sex/age group $(p=0.008)$. Furthermore, the significant result for trait P4-M2 in $\Sigma$ PCB (Table 4 ), changed to non-significant when using P4$\mathrm{M} 2_{\text {(Resid.) }}$. As the changes were so few and of no great consequence to the discussion, we decided to report the figures here, but not to change the method used throughout the paper.

Traits CBL and MH were size dependent until successfully transformed, using $[|R-L| /((R$ - L)/2)] (Palmer \& Strobeck 2003a). For all further analyses, traits $\mathrm{CBL}$ and $\mathrm{MH}$ were used in their transformed form, while all other traits were used untransformed. None of the nine traits showed significant anti-symmetry. See Bechshøft et al. (2008) for further information on calculations of asymmetry, measurement error, and repeatability.

All statistical analyses were performed using SPSS (version 13.0) (SPSS Inc., Chicago, Illinois). The significance level was set to $p=0.05$ unless other is specified.
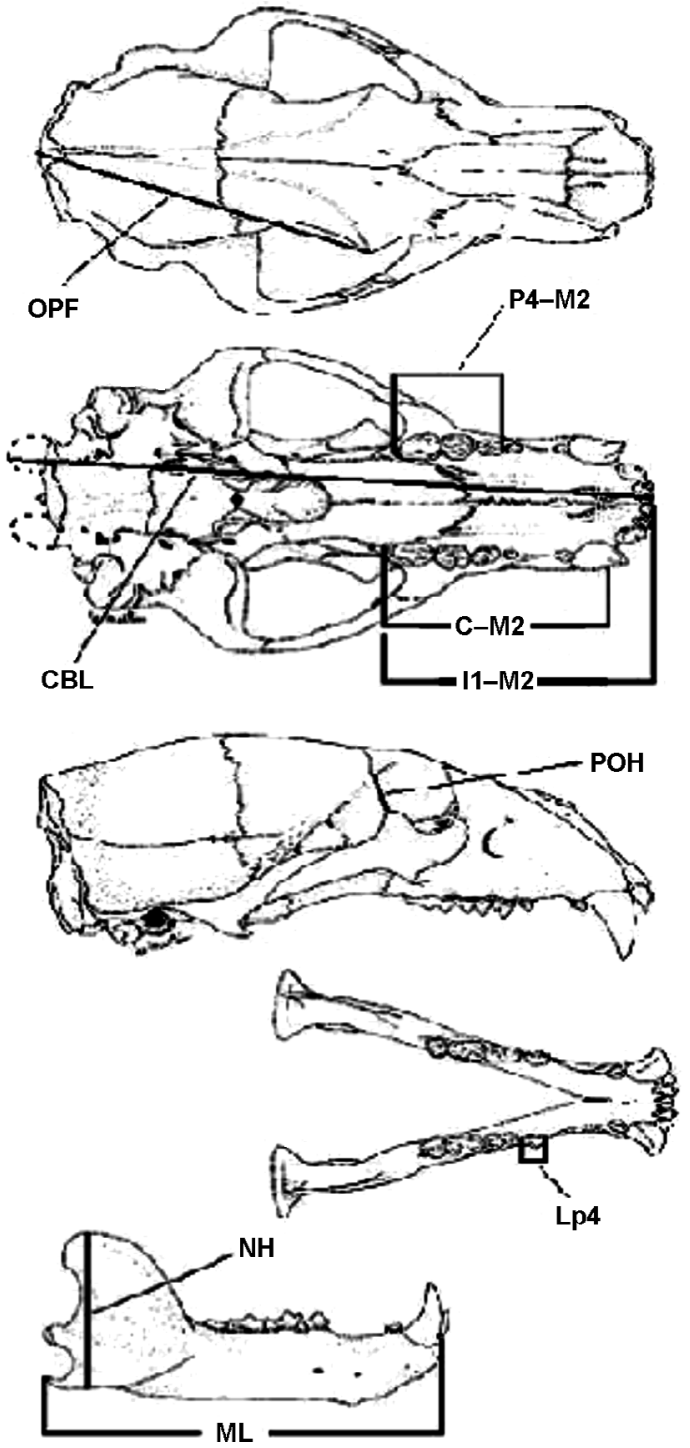

Fig. 1. Nine metric traits (see Table 2) measured on skulls of East Greenland and Svalbard polar bears (Ursus maritimus). Figure modified from Amstrup and DeMaster (1988).

\section{Bias}

FA may increase with increasing trait size (Leung 1998) and ME may increase with decreasing trait size (Merilä \& Björklund 1995). This could create bias in the sample if the skulls of bears of any one sex or locality were consistently found to be growing larger or smaller over the period of time during which the investigated polar bear 
Table 3. Significant factors and interactions from three-way ANOVAs (dependent variable: The absolute value of measured fluctuating asymmetry; independent variables: Locality, sex/age groups, periods) carried out on nine metric traits measured on skulls of East Greenland and Svalbard polar bears (Ursus maritimus), in order to estimate which variables play an important role in the differences observed in the measured fluctuating asymmetry.

\begin{tabular}{llr}
\hline & Factors and interactions with a significant contribution & $p$ \\
\hline OPF & Adult male/adult female/subadults & $<0.0001$ \\
CBL & None & 0.042 \\
P4-M2 & (Adult male/adult female/subadults $) \times(\leq 1960$ and $>1960)$ & \\
C-M2 & None & 0.005 \\
I1-M2 & Geographic locality & 0.020 \\
POH & Adult male/adult female/subadults & $<0.0001$ \\
Lp4 & None & 0.016 \\
ML & $\leq 1960$ and $>1960$ & 0.008 \\
$M L$ & (Geographic locality) $\times(\leq 1960$ and $>1960)$ & 0.015 \\
$M H$ & Adult male/adult female/subadults & \\
\hline
\end{tabular}

Table 4. Results from hierarchical multiple regression analyses (dependent variable: The absolute value of measured fluctuating asymmetry; explanatory variables: Contaminant levels in individual subcutaneous adipose tissue samples) carried out on nine metric traits measured on skulls of East Greenland polar bears (Ursus maritimus), in order to assess the degree to which the measured contaminant levels were able to predict the differences in the same individuals' measured levels of fluctuating asymmetry. Measurements of individual levels of PCBs, HCB, $\mathrm{HCHs}$, DDTs, dieldrin, CHLs, and PBDEs in subcutaneous adipose tissue were available from a subsample of 65 of the East Greenland polar bears (further details on the levels of the organohalogen compounds in relation to season, sex, and age are given in Dietz et al. (2004, 2007), Sandala et al. (2004), and Muir et al. (2006)).

\begin{tabular}{|c|c|c|c|c|c|c|c|c|c|c|}
\hline & & \multicolumn{9}{|c|}{ Trait } \\
\hline & & OPF & CBL & P4-M2 & $\mathrm{C}-\mathrm{M} 2$ & I1-M2 & $\mathrm{POH}$ & Lp4 & $M L$ & $\mathrm{MH}$ \\
\hline \multirow[t]{3}{*}{$\Delta R^{2(\mathrm{a}}$} & $M 1^{(a}$ & 1.5 & 2.2 & 1.2 & 3.4 & 7.7 & 7.3 & 3.0 & 0.8 & 10.0 \\
\hline & $M 2^{(a}$ & 25.2 & 19.5 & 13.6 & 9.6 & 23.9 & 24.0 & 6.1 & 8.1 & 16.0 \\
\hline & M total'a & 26.7 & 21.7 & 14.7 & 13.0 & 31.7 & 31.3 & 9.2 & 8.9 & 26.0 \\
\hline \multirow[t]{2}{*}{$\sum \mathrm{PCB}$} & $p$ & 0.418 & $0.037^{*}$ & 0.851 & 0.416 & 0.656 & $0.007^{*}$ & 0.811 & 0.877 & 0.381 \\
\hline & $B^{(\mathrm{b}}$ & $<0.0001$ & $<0.0001$ & $<0.0001$ & $<0.0001$ & $<0.0001$ & $<0.0001$ & $<0.0001$ & $<0.0001$ & $<0.0001$ \\
\hline \multirow[t]{2}{*}{$\mathrm{HCB}$} & $p$ & 0.435 & 0.709 & $0.044^{*}$ & 0.136 & $0.001^{*}$ & 0.647 & 0.770 & 0.389 & 0.113 \\
\hline & $B^{(\mathrm{b}}$ & -0.003 & $<0.0001$ & 0.004 & 0.004 & 0.006 & 0.001 & $<0.0001$ & -0.003 & $<0.0001$ \\
\hline \multirow[t]{2}{*}{$\Sigma \mathrm{HCH}$} & $p$ & 0.147 & 0.985 & 0.974 & 0.265 & 0.867 & $0.003^{*}$ & 0.997 & 0.797 & 0.755 \\
\hline & $B^{(b)}$ & -0.004 & $<0.0001$ & $<0.0001$ & -0.002 & $<0.0001$ & -0.005 & $<0.0001$ & 0.001 & $<0.0001$ \\
\hline \multirow[t]{2}{*}{$\Sigma D D T$} & $p$ & $0.004^{*}$ & 0.475 & 0.425 & 0.835 & 0.911 & 0.317 & 0.977 & 0.592 & 0.210 \\
\hline & $B^{(b)}$ & 0.003 & $<0.0001$ & $<0.0001$ & $<0.0001$ & $<0.0001$ & $<0.0001$ & $<0.0001$ & $<0.0001$ & $<0.0001$ \\
\hline \multirow[t]{2}{*}{ Dieldrin } & $p$ & 0.736 & 0.517 & 0.344 & 0.582 & 0.282 & 0.082 & 0.962 & 0.146 & 0.266 \\
\hline & $B^{(b}$ & 0.002 & $<0.0001$ & 0.003 & 0.002 & 0.003 & 0.004 & $<0.0001$ & 0.006 & $<0.0001$ \\
\hline \multirow[t]{2}{*}{$\Sigma \mathrm{CHL}$} & $p$ & 0.977 & 0.177 & 0.146 & 0.163 & 0.177 & $0.022^{*}$ & 0.581 & 0.258 & 0.231 \\
\hline & $B^{(b)}$ & $<0.0001$ & $<0.0001$ & -0.001 & -0.001 & $<0.0001$ & -0.001 & $<0.0001$ & -0.001 & $<0.0001$ \\
\hline \multirow[t]{2}{*}{$\sum$ PBDE } & $p$ & 0.189 & 0.157 & 0.181 & 0.965 & 0.996 & 0.651 & 0.147 & 0.838 & 0.688 \\
\hline & $B^{(\mathrm{b}}$ & 0.007 & $<0.0001$ & -0.004 & $<0.0001$ & $<0.0001$ & -0.001 & 0.001 & 0.001 & $<0.0001$ \\
\hline
\end{tabular}

* Statistically significant at $p=0.05$.

a) The $\Delta R^{2}$ is given by: $\mathrm{M} 1$; number of percent of the measured variation in absolute FA explained by age and sex of the individuals. M2; additional number of percent of the measured variation in absolute FA explained by the regression model, when levels of contaminants are brought in as explanatory variables as well. $\mathrm{M}$ total = total number of percent of the measured variation in absolute FA explained by the regression model.

b) The unstandardized coefficients $(B)$ denote the parameter estimates one would use when creating the equation calculated by the regression model for each individual trait. 
skulls were collected. Condylobasal length was chosen to represent general size. Two three-way ANOVAs (one on the subadults and one on the adults) were applied to test for size bias over time, with condylobasal length (from the first of the repeated measurements) as $\left(\mathrm{CBL}_{\text {right }}+\right.$ $\left.\mathrm{CBL}_{\text {left }}\right) / 2$. The first ANOVA was conducted with condylobasal length as the dependent variable, and locality, sex/age groups (here: subadults, divided into males and females), and periods ( $\leq 1960$ and $>1960)$ as independent variables. The second ANOVA was conducted with condylobasal length as the dependent variable, and locality, sex/age groups (here: adults, divided into males and females), and periods ( $\leq 1960$ and $>1960$ ) as independent variables.

\section{Outliers}

Possible outliers, with regards to measurements, were identified from scatter plots as suggested by Palmer and Strobeck (2003b). The outliers were then tested and removed according to Grubbs' test (Grubbs 1969, Palmer \& Strobeck 2003b).

\section{FA in relation to sex/age groups, periods, and localities}

A three-way ANOVA (dependent variable: FA $(|R-L|)$, independent variables: locality, sex/age groups, and periods) was carried out for each trait in order to estimate which factors played an important role for differences in the observed FA. Prior to this, a one-way ANOVA was conducted on the traits in order to justify the pooling of the sexes in the subadult group (dependent variable: FA $(|R-L|)$, factor: subadult males $v s$. subadult females), and the segregation of the sexes in the adult individuals (dependent variable: FA $(|R-L|)$, factor: adult males $v s$. adult females). Games-Howell and Tukey's HSD post-hoc tests were applied in the analyses of two traits (OPF and $\mathrm{POH})$. The time of the split between the two periods ( $\leq 1960$ and $>1960$ ) was chosen because outputs and use of for example PCBs, one of the major organochlorines, began being widely used in the 1950s and peaked in the 1960s (AMAP 2004, Dietz et al. 2004).
If an organism-wide level of FA exists, each trait would in theory add some information about it. As each trait ideally provides an independent measure of the organism's FA, combining the information from multiple traits ought to give a stronger analysis (Palmer \& Strobeck 2003a). Therefore, FA data $(|\ln (R)-\ln (L)|)$ for traits C-M2, I1-M2, POH, and Lp4 were pooled and run in a four-way ANOVA (dependent variable: $|\ln (R)-\ln (L)|$, pooled for the four aforementioned traits, fixed factors: locality, sex/age groups, periods, and trait). The log-transformation was applied in order to remove any scale effect among the four traits.

\section{FA over time}

The analyses of temporal variation in FA were run only on polar bears born in 1950 or later, as the individuals born before that time were too few to conduct continuous time-trend analyses on. The East Greenland and Svalbard samples were pooled in the analyses. The two samples were roughly equal as to number of males and females, as well as number of adult males, adult females, and subadults (see Table 1). Trait I1-M2 was not included in the analysis, as it showed a geographical difference (see Results). A scatterplot of the FA $(I R-L I)$ of each of the remaining traits versus the birth year of the individuals was produced for each sex/age group. Linear regression lines (including 95\% confidence intervals) and LOESS (locally weighted scatterplot smoothing) lines were added to each scatterplot. The LOESS line was applied to allow the data to reveal its own natural pattern (Cleveland 1979, Prince \& Silva 2002, Vieth et al. 2003). As the LOESS line confirmed the linearity of the relationship between year of birth and FA for the nine traits, Pearson correlation analyses were performed for each sex/age group on each trait, assessing the degree to which the individuals' year of birth had a significant effect on the observed FA.

\section{FA and contaminant levels}

Hierarchical multiple regression analyses (FA (IR 
$-L I)$ as dependent variable; sex and age in years, and contaminants as explanatory variables) were conducted in order to assess the degree to which individual contaminant levels were able to predict the differences in the individual levels of FA. The explanatory variables were entered in two steps; first sex and age in years (model 1, M1), then contaminants (model 2, M2). In this way, variables were assessed in terms of what they added to the prediction of the dependent variable.

\section{Results}

\section{Identification of sex}

For the Svalbard subadult sample, trait P4M2 was the best parameter for distinguishing between males and females, with $86.7 \%$ correctly identified. An additional 27 subadult individuals were sexed according to this model. For the Svalbard adult sample, the model consisting of traits $\mathrm{P} 4-\mathrm{M} 2$ and $\mathrm{I} 1-\mathrm{M} 2$ was the best (91.0\% accuracy), determining the sex of a high number of individuals of previously unknown sex $(n=63)$. This model was also the best for the East Greenland subadult sample, as it identified a high percentage of the bears of known sex (88.0\% accuracy) and also determined the sex of a high number of individuals of previously unknown sex $(n=38)$.

The unstandardized canonical discriminant functions were estimated as seen below. Cutting scores were calculated as described in Hair et al. (2006).

Svalbard adults:

$D=-25.11+0.20 \times$ length of trait P4-M2 $2_{\text {right }}$ $+0.09 \times$ length of trait I1-M 2 right

(Male group centroid: 1.08, female group centroid: -1.56 .

Cutting score -0.48$)$.

Svalbard subadults:

$D=-20.83+0.36 \times$ length of trait $\mathrm{P} 4-\mathrm{M} 2_{\text {right }}(2)$

(Male group centroid: 0.77, female group centroid: -0.96 .

Cutting score -0.19 ).
East Greenland subadults:

$D=-23.76+0.21 \times$ length of trait $\mathrm{P} 4-\mathrm{M} 2$ right

$+0.09 \times$ length of trait I1-M $2_{\text {right }}$

(Male group centroid: 1.18, female group centroid: -1.27 .

Cutting score -0.09 ).

\section{Bias}

The three-way ANOVA testing for bias of condylobasal length over time in the subadult sample showed that CBL was larger during the early period $(\leq 1960)(p=0.013)$, especially for the Svalbard polar bears. There was no observed temporal bias in size for the adult sample.

\section{Outliers}

Of the outliers identified from the scatter plots and run through Grubbs' test (Grubbs 1969), a total of 126 measurements $(R$ and $L)$ were excluded from the statistical analysis, which corresponds to $2.0 \%$ of all measurements taken.

\section{FA in relation to sex/age groups, periods, and localities}

The one-way ANOVA of FA showed no significant differences between subadult males and subadult females in any traits $(0.101 \leq p \leq$ 0.997), and the groups were thus pooled into a single group of subadults. The analyses of adult males $v s$. adult females revealed significant differences in regard to their FA in three of the nine traits (males having higher levels of FA), and the groups were therefore kept separate in the further FA calculations. There were significant results from the three-way ANOVA estimating FA within periods, locations, and sex/age groups (Table 3): The FA of traits OPF ( $p<$ $0.0001)$ and $\mathrm{POH}(p=0.020)$ differed significantly among the sex/age groups. Games-Howell (for OPF) and Tukey's HSD (for POH) post-hoc tests showed that adult males had a significantly higher FA than subadults (OPF: $p<0.0001$, POH: $p=0.046$ ) and adult females (OPF: $p<$ 

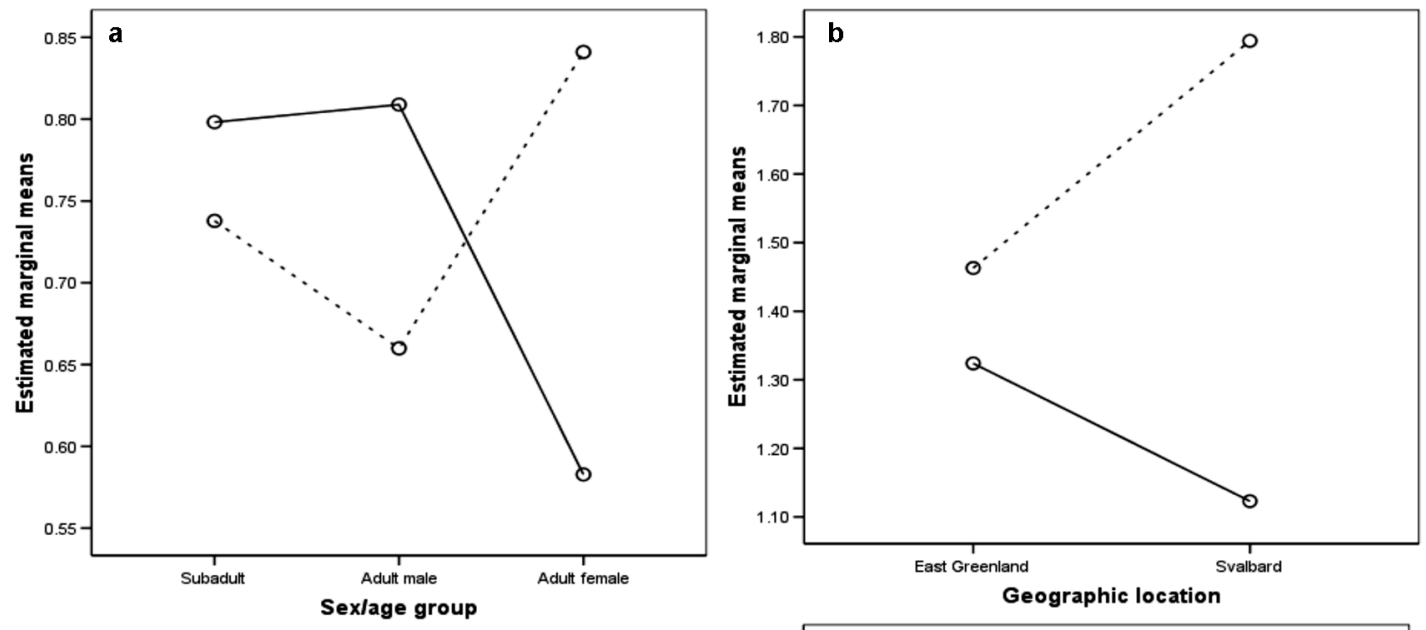

Fig. 2. Plots of significant interactions from three-way ANOVAs (dependent variable: the absolute value of measured fluctuating asymmetry; independent variables: locality, sex/age groups, periods) carried out on nine metric traits measured on skulls of East Greenland and Svalbard polar bears (Ursus maritimus), in order to estimate which variables play an important role in the differences observed in the measured fluctuating asymmetry. (a) Trait P4-M2, (b) trait ML, (c) trait MH. Dotted line $=$ individuals born $\leq 1960$, continuous line $=$ individuals born $>1960$.

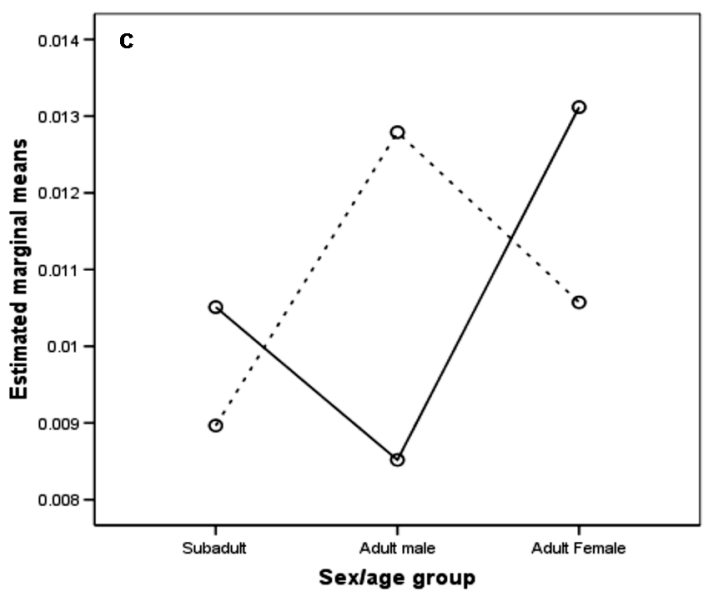

0.0001, POH: $p=0.036)$. In traits $\mathrm{P} 4-\mathrm{M} 2$ and $\mathrm{MH}$, the interaction between sex/age groups and periods was significant (P4-M2: $p=0.042 ; \mathrm{MH}$ : $p=0.015)$. In trait $\mathrm{P} 4-\mathrm{M} 2$ subadults as well as adult males had a lower FA during the first period than during the second period (Fig. 2a). The pattern for trait P4-M2 of the adult females was the opposite, with a clearly lower FA during the second period. In the interaction in trait $\mathrm{MH}$, adult males had a markedly lower FA during the second period, whereas the pattern for both subadults and females were the exact opposite, with highest FA-values in the second period (Fig. 2c).

The FA of trait I1-M2 was significantly higher $(p=0.005)$ in the Svalbard bears. The polar bears (irrespective of sample locality and sex/age group) born $\leq 1960$ had a higher FA in trait ML than those born $>1960(p<0.0001)$.

Trait ML was also determined by the interaction effect between geographic locality and periods ( $p=0.016$ ); all polar bears from East Greenland as well as those from Svalbard had a higher FA during the early period (Fig. 2b). The difference between the two periods was by far the greatest in the Svalbard subpopulation (Fig. 2b).

The four-way ANOVA on the pooled four traits showed that trait $(p<0.0001)$ and locality $(p=0.030)$ were significant factors within the model. Trait POH held the highest FA followed by Lp4, C-M2, and finally I1-M2. All traits were significantly different from each other $(p<0.0001)$, except for C-M2 and I1-M2 ( $p$ $=0.198)$. The Svalbard polar bears had a significantly higher FA $(p=0.030)$ than those from East Greenland. All other factors, main as well as interactions, were non-significant. 


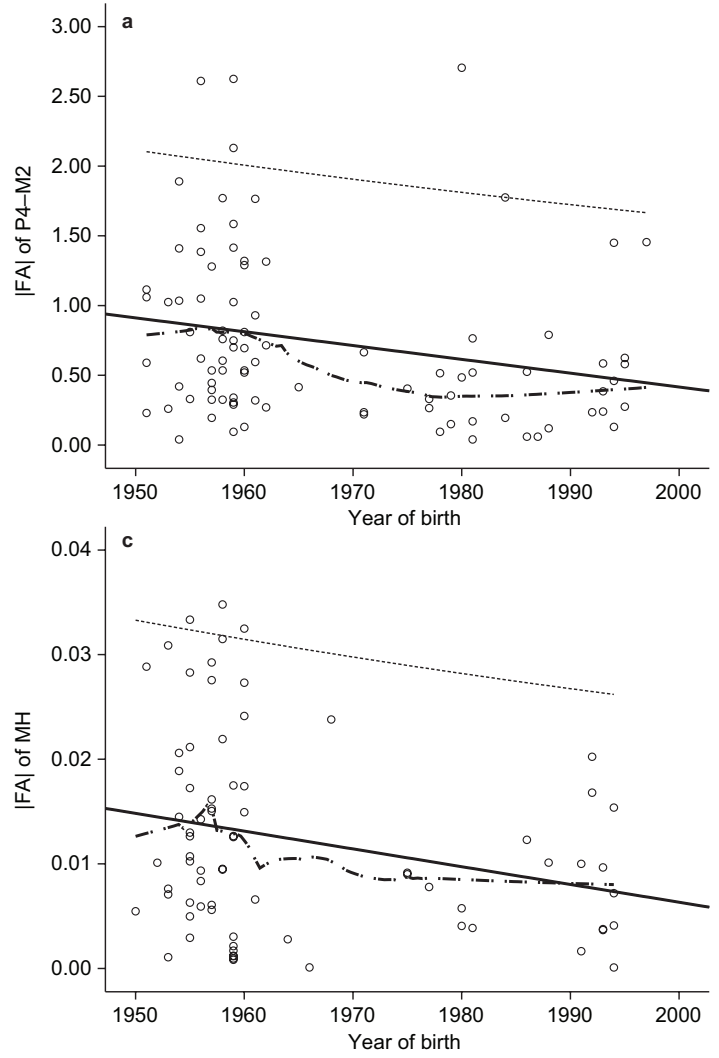

\section{FA over time}

For all traits, the linear regression and the LOESS lines largely followed the same path (Fig. 3), which rendered the linear correlation a plausible model for the nine traits in each subgroup (Cleveland 1979, Prince \& Silva 2002, Vieth et al. 2003). There was a clear trend in the three significant results from the Pearson correlation analyses, as they all exhibited a negative correlation of FA over time: adult females, traits P4-M2 (Fig. 3a: $r$ $=-0.232, p=0.028$ ) and ML (Fig. 3b: $r=-0.228$, $p=0.046$ ), and adult males, trait MH (Fig. 3c: $r$ $=-0.268, p=0.020)$. There was no clear negative or positive tendency for the remainder of the results of the correlation analyses.

\section{FA and contaminant levels}

There were seven instances (out of $63=9$ traits $\times 7$ contaminant groups) of regression analyses where contaminant groups had a significant influ-

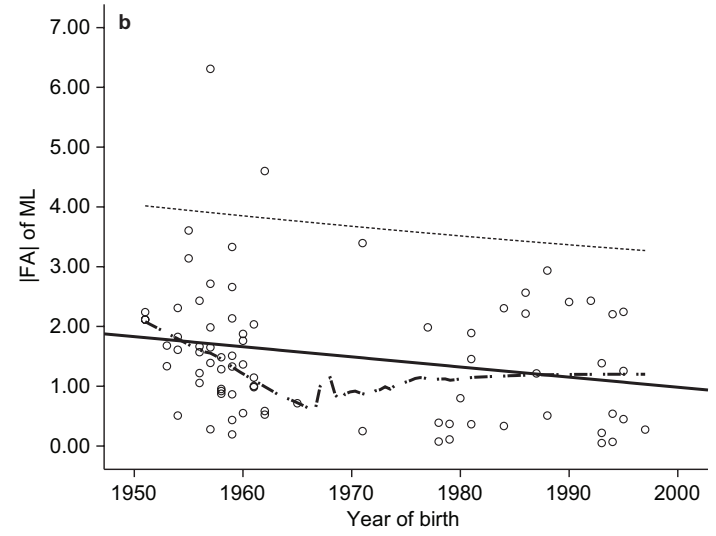

Fig. 3. Scatterplots of metric traits measured on the skulls of East Greenland and Svalbard polar bears (Ursus maritimus) vs. the individuals' year of birth (born $\geq$ 1950). - : linear regression: - - -: 95\% confidence intervals; · - . - - LOESS line. (a) trait P4-M2; adult females, $r=-0.232, p=0.028$, (b) trait ML; adult females, $r=-0.228, p=0.046$, (c) trait $\mathrm{MH}$; adult males, $r$ $=-0.268, p=0.020$.

ence on the FA of individual traits; $\Sigma$ DDT in trait OPF $(B=0.003, p=0.0004), \Sigma \mathrm{PCB}$ in trait CBL $(B<0.0001, p=0.037), \mathrm{HCB}$ in traits $\mathrm{P} 4-\mathrm{M} 2$ $(B=0.004, p=0.044)$ and $\mathrm{I} 1-\mathrm{M} 2(B=0.006$, $p=0.001)$, and $\Sigma$ PCB $(B<0.0001, p=0.007)$, $\sum \mathrm{HCH}(B=-0.005, p=0.003)$ and $\Sigma \mathrm{CHL}(B=$ $-0.001, p=0.022)$ in trait POH (Table 4). Sex and age of the polar bears explained between $0.8 \%$ and $10.0 \%$ of the variation in the measured FA (M1 in Table 4), whereas the contaminant levels explained between $6.10 \%$ and $25.2 \%$ of the variation in the measured FA (M2 in Table 4). When both factors (age and sex, and contaminant levels) were taken into account in the model, between $8.90 \%$ and $31.70 \%$ of the measured variation in FA was explained (M total in Table 4).

\section{Discussion}

\section{Identification of sex}

Classificatory analyses for identification of 
sex were performed on Svalbard subadults and adults, and on East Greenland subadults. All models primarily included the trait P4-M2, which was also applied previously by Larsen (1971) in sex identification of polar bears.

\section{Bias}

FA may increase with increasing trait size (Leung 1998). This could create bias in the sample if the skulls were consistently found to be growing larger or smaller over the period during which the investigated polar bear skulls were collected. The three-way ANOVA assessing bias of condylobasal length of subadult polar bears over time showed that the CBL of the subadults was significantly longer during the first period $(\leq 1960)$, especially for the Svalbard subadults. These results could be caused by the limited number of subadult Svalbard polar bears available from the earlier period compared to the second period. This bias must be taken into consideration when interpreting other results pertaining to the subadult bears in the present FA study.

\section{Outliers}

In the present study, $2.0 \%$ of the FA data were identified and treated as outliers. In comparison, Ahtiainen et al. (2003) identified $2.1 \%$ of their FA data as outliers, and of the data from Crespi and Vanderkist (1997), Palmer and Strobeck (2003b) identified $5.7 \%$ as outliers.

\section{FA in relation to sex/age groups, periods, and localities}

Trait ML of all sex/age groups had a FA which proved significantly higher during the first period than during the second. This obviously goes against the theory of pollution as generator of increasing FA. This could be due to the DA of the trait, or perhaps the change is instead caused by other extrinsic factors than pollution; e.g. population density, temperatures, or prey availability. Also, it could partly be a result of the previously mentioned bias in size over time found in the subadult sample. The results for the interaction between traits $\mathrm{P} 4-\mathrm{M} 2$ and $\mathrm{MH}$, respectively, and the two periods were rather inconsistent, again perhaps due to the DA of trait P4-M2. The only sex/age group that showed the same trend for both interactions was subadults; in traits P4-M2 and MH the subadults had a significantly higher FA during the second period than they did during the first. Perhaps the reason is that the subadult bears are under more severe stress during their phase of rapid growth (Derocher \& Wiig 2002), with the fatty mother's milk they consume at this sensitive stage of their life containing high levels of organohalogens (Bernhoft et al. 1997, Polischuk et al. 2002). An organism's DS is often believed to be largely determined during the foetal stage (Siegel et al. 1977b, Møller \& Swaddle 1997, Valetsky et al. 1997). Still, the trait can apparently also be influenced to a certain extent throughout the organisms' entire lifespan. Møller and Swaddle (1997) suggest that the DS may depend on the nature of the trait, i.e. how functionally important it is to the organism. Vertebrate bones for example are capable of significant remodeling (Olsen et al. 2000). Therefore, aspects such as canalization (Nijhout \& Davidowitz 2003) and plasticity (Nijhout \& Davidowitz 2003, Palmer \& Strobeck 2003a) are also important concerns.

Svalbard polar bears had significantly higher FA in trait I1-M2 than did the bears from East Greenland, a trend which was reflected in the outcome of the pooling of four of the traits. This gives reason to believe that the trend of Svalbard polar bears having higher FA levels than East Greenland polar bears could well be a trend in other traits too, although too faint to be detected when each trait is analyzed on its own. A geographical difference between the two subpopulations was also found by Sonne et al. (2007), with the Svalbard bears having a higher ratio of tooth wear than the East Greenland bears. Sonne et al. (2007) ascribed the observation to differences in bone consumption (food competition) caused by population density and food availability. Perhaps the difference in FA could also be ascribed to the speculated increased polar bear population found in Svalbard (Derocher 2005).

The adult males had significantly higher FA than both adult females and subadults in traits $\mathrm{OPF}$ and $\mathrm{POH}$. The explanations for this lie in 
speculations only; perhaps the males are generally under more stress than the other two sex/age groups, perhaps they differ in plasticity which could potentially affect their FA levels, or perhaps this could be a case of greater body size causing higher variance (Pertoldi et al. 2007). Should either of these hypotheses be true though, one would perhaps expect the adult males to stand out significantly from the other two sex/ age groups in more than just two traits.

One could also speculate as to the choice of year of split between non-polluted and polluted periods. Perhaps a division into three periods could have been an option, as many of the "old" organochlorines have shown indications of decrease recently (Derocher et al. 2003, Dietz et al. 2004, Verreault et al. 2005, Riget 2005). Change in FA over time was therefore further analysed.

\section{FA over time}

All three significant results from the correlation analyses of FA over time (with the two subpopulations merged into one) were negatively sloped; traits $\mathrm{P} 4-\mathrm{M} 2$ and $\mathrm{ML}$ in the adult females, and trait $\mathrm{MH}$ in the adult males. The results for the females could be confounded by the DA found in traits P4-M2 and ML. Assuming that FA is an indicator of stress, the East Greenland and Svalbard polar bear subpopulations seem to have become progressively less stressed over time since the 1950s, in spite of possible effects of excessive harvesting (Lønø 1970, Larsen 1986, Wiig 2005), pollution (Norstrom et al. 1998, Skaare et al. 2000, Derocher et al. 2003, AMAP 2004, Braathen et al. 2004, Verreault et al. 2005, Muir et al. 2006), and a warming climate (ACIA 2005, Regehr et al. 2005, Wiig 2005).

If factors such as temperature or other extrinsic stressors have shifted considerably over the period during which the skulls were collected, it could explain why FA was found higher in the earlier period. Higher climatic fluctuations (temperature extremes) during the earlier period could have led to a decline in prey availability and thus starvation-induced stress and FA in the polar bears. However, this hypothesis is not likely, as temperatures above normal have been experienced in the Arctic during the last decades (ACIA 2005, Sonne et al. 2005a). Earlier studies of marine mammals detected differences in FA over time, connected to pollution (Zakharov \& Yablokov 1990, Schandorff 1997). However, in these studies, PCB and DDT concentrations were up to a hundred times higher than those found in the present study (see e.g. Olsson \& Reutergårdh 1986, Blomkvist et al. 1992).

Apparently there must also exist other factors than the abovementioned to be reckoned with when assessing the state of these two polar bear subpopulations. It has recently been speculated that the Svalbard polar bear subpopulation, which was previously so heavily depleted (Lønø 1970, Larsen 1986), may now have reached a level of recovery where individual growth becomes density dependent (Derocher 2005). This would indicate that the subpopulation growth was currently at or beyond its peak. The present results, however, indicate that density dependence is not yet to be reckoned a stress factor for the East Greenland and Svalbard polar bear subpopulations. An alternative explanation could simply be that FA of metric skull traits is not a suitable predictor of stress in polar bears. However, metric skull traits have been successfully applied as measurers of stress in other species (Siegel et al. 1977b, Pertoldi et al. 2000a, Hoelzel et al. 2002).

A more speculative explanation for the decrease in FA found in the present study could be the declining pollution rates in most of the "older" organohalogens (Derocher et al. 2003, Dietz et al. 2004). Concentrations of pollutants such as those examined in the present study have decreased ca. 20\%-70\% since 1990 (Dietz et al. 2004). Were these organohalogen concentrations extrapolated back in time, values observed around ca. 1965 would in all probability be in the same range as those used by Zakharov and Yablokov (1990) and Schandorff (1997). This would support our hypothesis of metric FA being linked to organohalogen pollutants in polar bears. However, no data is present to support this, and the existence of such a link thus remains uncertain.

\section{FA and contaminant levels}

The majority of the significant results from the 
multiple regressions between FA and contaminant levels were positively correlated. However, parameter estimates $(B)$ for all seven significant results were very low. This means that although a trend supporting the theory of increased pollution levels leading to more stress and higher FA was found, no clear picture emerged. None of the few other studies attempting this correlation between FA and contaminants on an individual level had particularly higher success in linking the two factors (Pertoldi et al. 1997, Hendrickx et al. 2003). The pollutants supposedly have their greatest effect on the individual at the foetal stage (e.g. Siegel et al. 1977b, Møller \& Swaddle 1997, Valetsky et al. 1997). This is why the model was tested for influence by age. However, age and sex, even together, did not explain much of the variation found in the measured FA (M1, Table 4); the pollutants themselves explained a great deal more (M2, Table 4). As when analysing FA over time, one must probably take factors other than pollution into consideration when assessing the causes of fluctuating asymmetry. Perhaps FA of metric skull traits is not a suitable predictor of pollution-induced stress in polar bears. Or perhaps the organohalogen toxic loads are not at high enough levels to elicit a measurable positive response in the FA of the examined polar bears. Schandorff (1997), and Zakharov and Yablokov (1990) found that high levels of FA were associated with high levels of pollutants, but the pollutant concentrations in these studies by far exceeded the ones in the present study, as also mentioned earlier.

The present FA study was in part motivated by the results of Sonne et al. (2005a). The aim was to achieve better and more robust results when linking the FA of the bears to time, and to organohalogen loads in and around them. This was attempted by including a higher number of bears, and by applying more exact measuring equipment and methods. The measuring methods and statistical approach of the present study succeeded in being more robust; in particular in regards to the repeated measurements of all traits, which provided an excellent basis for comparing measurement errors and levels of FA (Bechsh $\varnothing \mathrm{ft}$ et al. 2008). However, this did not help create a markedly clearer picture than the one obtained in Sonne et al. (2005a) when linking the FA of the polar bears to time and organohalogen loads. As the metric traits used in this study were measured, foramina were counted on the same polar bear skulls. Analysing these meristic data for FA is a natural next step, and may help clarify the picture.

\section{Conclusions}

The results indicated that Svalbard bears generally had a higher level of FA than those of East Greenland. Subadult polar bears were found to have higher FA in two traits during the late period (>1960), while adult males were found to have generally higher FA in two traits than the other sex/age groups. Overall, the present study showed no substantial evidence of a linkage between levels of FA and organohalogens. Instead, the indications were of subpopulations with generally declining levels of FA over time, suggesting the existence of positive population level effects powerful enough to overrule the negative influence of stress caused by global warming, pollution, and overharvesting.

\section{Acknowledgements}

The Zoological Museum, University of Copenhagen, Denmark and the Natural History Museum, University of Oslo, Norway are acknowledged for providing access to their collections of polar bear skulls. Erik W. Born is acknowledged for valuable comments to the manuscript.

\section{References}

ACIA 2005: Arctic climate impact assessment. - Cambridge University Press, Cambridge.

Ahtiainen, J. J., Alatalo, R. V., Mappes, J. \& Vertainen, L. 2003: Fluctuating asymmetry and sexual performance in the drumming wolf spider Hygrolycosa rubrofasciata. - Annales Zoologici Fennici 40: 281-292.

AMAP 2004: AMAP assessment 2002: Persistent organic pollutants in the Arctic. - Arctic Monitoring and Assessment Programme, Oslo.

Amstrup, S. C. \& DeMaster, D. P. 1988: Polar bear (Ursus maritimus). Biology, management and conservation. - In: Lentfer, J. W. (ed.), Selected marine mammals of Alaska: Species accounts with research and management recommendations: 39-56. Marine Mammal Commission, Washington, DC. 
Andersen, D. H., Pertoldi, C., Loeschcke, V. \& Scali, V. 2006: Developmental instability, hybridization and heterozygosity in stick insects of the genus Bacillus (Insecta, Phasmatodea) with different modes of reproduction. - Biological Journal of the Linnean Society 87: 249-259.

Baranov, A. S., Pucek, Z., Kiseleva, E. G. \& Zakharov, V. M. 1997: Developmental stability of skull morphology in European bison Bison bonasus. - Acta Theriologica Suppl. 4: 79-85.

Bernhoft, A., Wiig, Ø. \& Skaare, J. U. 1997: Organochlorines in polar bears (Ursus maritimus) at Svalbard. - Environmental pollution 95: 159-175.

Bechshøft, T. Ø., Rigét, F. F., Wiig, Ø. \& Sonne, C. 2008: Fluctuating asymmetry in metric traits; a practical example of calculating asymmetry, measurement error, and repeatability. - Annales Zoologici Fennici 45: 32-38.

Blomkvist, G., Roos, A., Jensen, S., Bignert, A. \& Olsson, M. 1992: Concentrations of DDTs and PCB in seals from Swedish and Scottish Waters. - Ambio 8: 539-545.

Borgå, K., Gabrielsen, G. W. \& Skaare, J. U. 2001: Biomagnificatin of organochlorines along a Barents Sea food chain. - Environmental Pollution 113: 187-198.

Borisov, V. I., Baranov, A. S., Valetsky, A. V. \& Zakharov, V. M. 1997: Developmental stability of the mink Mustela vison under the impact of PCB. - Acta Theriologica Suppl. 4: 17-26.

Borrell, Y. J., Pineda, H., McCarthy, I., Vasquez, E., Sanchez, J. A. \& Lizana, G. B. 2004: Correlations between fitness and heterozygosity at allozyme and microsatellite loci in the Atlantic salmon, Salmo salar L. - Heredity 92: 585-593.

Bossi, R., Riget, F. F., Dietz, R., Sonne, C., Fauser, P., Dam, M. \& Vorkamp, K. 2005: Preliminary screening of perfluorooctane sulfonate (PFOS) and other fluorochemicals in fish, birds and marine mammals from Greenland and the Faroe Islands. - Environmental Pollution 136: 323-329.

Braathen, M., Derocher, A. E., Wiig, Ø., Sørmo, E. G., Lie, E., Skaare, J. U. \& Jenssen, B. M. 2004: Relationships between PCBs and thyroid hormones and retinol in female and male polar bears. - Environmental Health Perspectives 112: 826-833.

Clarke, G. M. 1995: Relationship between developmental stability and fitness: Application for conservation biology. - Conservation Biology 1: 18-24.

Cleveland, W. S. 1979: Robust locally weighted regression and smoothing scatterplots. - Journal of the American Statistical Association 74(368): 829-836.

Corsolini, S., Kannan, K., Imagawa, T., Focardi, S. \& Giesy, J. P. 2002: Polychloronaphtalenes and other dioxin-like compounds in Arctic and Antarctic marine food webs. Environmental Science \& Technology 36: 3490-3496.

Crespi, B. J. \& Vanderkist, B. A. 1997: Fluctuating asymmetry in vestigial and functional traits of a haploid insect. - Heredity 79: 624-630.

Derocher, A. E. 2005: Population ecology of polar bears at Svalbard, Norway. - Population Ecology 47: 267-275.

Derocher, A. E. \& Wiig, Ø. 2002: Postnatal growth in body length and mass of polar bears (Ursus maritimus) at
Svalbard. - Journal of Zoology 256: 343-349.

Derocher, A. E., Wiig, Ø. \& Andersen, M. 2002: Diet composition of polar bears in Svalbard and the western Barents Sea. - Polar Biology 25: 448-452.

Derocher, A. E., Wolkers, H., Colborn, T., Schlabach, M., Larsen, T. S. \& Wiig, Ø. 2003: Contaminants in Svalbard polar bear samples archived since 1967 and possible population level effects. - The Science of the Total environment 301: 163-174.

Dietz, R., Heide-Jørgensen, M. P., Teilmann, J., Valentin, N. \& Härkönen, T. 1991: Age determination in European Harbour seals Phoca vitulina L. - Sarsia 76: 17-21.

Dietz, R., Riget, F. F., Sonne-Hansen, C., Letcher, R. J., Born, E. W. \& Muir, D. C. G. 2004: Seasonal and temporal trends in polychlorinated biphenyls and organochlorine pesticides in East Greenland polar bears (Ursus maritimus), 1990-2001. - Science of the Total Environment 331: 107-124.

Dietz, R., Riget, F. F., Sonne, C., Muir, D. C. G., Backus, S., Born, E. W., Kirkegaard, M. \& Letcher, F. J. 2007: Age and seasonal variability of polybrominated diphenyl ethers in free-ranging East Greenland polar bears (Ursus maritimus). - Environmental Pollution 146: 166-173.

Gebbink, W. A., Sonne, C., Dietz, R., Kirkegaard, M., Born, E. W., Muir, D. C. G. \& Letcher, R. J. 2008: Tissue-specific composition and body burdens of organohalogen and associated metabolite contaminant in polar bears (Ursus maritimus) from East Greenland. - Environmental Science and Technology. [In press].

Gibbs, M. \& Breuker, C. 2006: Effect of larval-rearing density on adult life-history traits and developmental stability of the dorsal eyespot pattern in the speckled wood butterfly, Pararge aegeria. - Entomologia Experimentalis et Aplicata 18: 41-47.

Green, C. C. \& Lochmann, S. E. 2006: Fluctuating asymmetry and condition in golden shiner (Notemigonus crysoleucas) and channel catfish (Ictalurus punctatus) reared in sublethal concentrations of isopropyl methylphosphonic acid. - Environmental Toxicology and Chemistry 25: 58-64.

Grubbs, F. E. 1969: Procedures for detecting outlying observations in samples. - Technometrics 11: 1-21.

Hair, J. F. Jr., Black, W. C., Babin, B. J., Anderson, R. E. \& Tatham, R. L. 2006: Multivariate data analysis, 6th ed. - Pearson Education, Inc., New Jersey.

Hendrickx, F., Maelfait, J.-P. \& Lens, L. 2003: Relationship between fluctuating asymmetry and fitness within and between stressed and unstressed populations of the wolf spider Pirata piraticus. - Journal of Evolutionary Biology 16: 1270-1279.

Hensel, R. J. \& Sorensen, F. E. 1980: Age determination of five polar bears. - International Conference on Bear Research and Management 4: 93-100.

Hoelzel, A. R., Fleischer, R. C., Campagna, C., Le Boeuf, B. J. \& Alvord, G. 2002: Impact of a population bottleneck on symmetry and genetic diversity in the northern elephant seal. - Journal of Evolutionary Biology 15: 567-575.

Jagoe, C. H. \& Haines, T. A. 1985: Fluctuating asymmetry in fishes inhabiting acidified and unacidified lakes. 
- Canadian Journal of Zoology 63: 130-138.

Jones, J. C., Helliwell, P., Beekman, M., Maleszka, R. \& Oldroyd, B. P. 2005: The effects of rearing temperature on developmental stability and learning and memory in the honey bee, Apis mellifera. - Journal of comparative physiology A 191: 1121-1129.

Kirkegaard, M., Sonne, C., Leifsson, P. S., Dietz, R., Born, E. W., Letcher, R. J. \& Muir, D. C. G. 2005: Histology of selected immunological organs in polar bear (Ursus maritimus) from East Greenland in relation to concentrations of organohalogen contaminants. - Science of the Total Environment 341: 119-132.

Lajus, D. L. \& Alekseev, V. R. 2004: Phenotypic variation and developmental instability of life-history traits: A theory and a case study on within-population variation of resting eggs formation in Daphnia. - Journal of Limnology 63, Suppl. 1: 37-44.

Larsen, T. 1971: Sexual dimorphism in the molar rows of the polar bear. - The Journal of Wildlife Management 35: 374-377.

Larsen, T. 1986: Population biology of the polar bear (Ursus maritimus) in the Svalbard area. - Norsk Polarinstitutt Skrifter 184: 1-53.

Leung, B. 1998: Correcting for allometry in studies of fluctuating asymmetry and quality within samples. Proceedings of the Royal Society of London B 265: 1623-1629.

Lie, E., Larsen, H. J. S., Larsen, S., Johansen, G. M., Derocher, A. E., Lunn, N. J., Norstrom, R. J., Wiig, Ø. \& Skaare, J. U. 2004: Does high organochlorine (OC) exposure impair the resistance to infection in polar bears (Ursus maritimus)? Part I: Effects of OCs on the humoral immunity. - Journal of Toxicology and Environmental Health A 67: 555-582.

Lønø, O. 1970: The polar bear (Ursus maritimus Phipps) in the Svalbard area. - Norsk Polarinstitutt Skrifter 149: $1-115$.

Maul, J. D. \& Farris, J. L. 2005: Monitoring exposure of northern cardinals, Cardinalis cardinalis, to cholinesterase-inhibiting pesticides: enzyme activity, reactivations, and indicators of environmental stress. - Environmental Toxicology and Chemistry 24: 1721-1730.

Merilä, J. \& Björklund, M. 1995: Fluctuating asymmetry and measurement error. - Systematic Biology 44: 97-101.

Muir, D. C. G., Backus, S., Derocher, A. E., Dietz, R., Evans, T. J., Gabrielsen, G. W., Nagy, J., Norstrom, R. J., Sonne, C., Stirling, I., Taylor, M. K. \& Letcher, R. J. 2006: Brominated flame retardants in polar bears (Ursus maritimus) from Alaska, the Canadian Arctic, East Greenland, and Svalbard. - Environmental Science \& Technology 40: 449-455.

Møller, A. P. 2006: A review of developmental instability, parasitism and disease infection, genetics and evolution. - Infection Genetics and Evolution 6: 133-140.

Møller, A. P. \& Swaddle, J. P. 1997: Asymmetry, developmental stability, and evolution. - Oxford University Press, Oxford.

Nijhout, H. F. \& Davidowitz, G. 2003: Developmental perspectives on phenotypic variation, canalization, and fluctuating asymmetry. - In: Polak, M. (ed.), Developmen- tal instability. Causes and consequences: 3-13. Oxford University Press, Oxford.

Norstrom, R. J., Belikov, S. E., Born, E. W., Garner, G. W., Malone, B., Olpinski, S., Ramsay, M. A., Schliebe, S., Stirling, I., Stishov, M. S., Taylor, M. K. \& Wiig, Ø. 1998: Chlorinated hydrocarbon contaminants in polar bears from eastern Russia, North America, Greenland, and Svalbard: Biomonitoring of Arctic pollution. Archives of Environmental Contamination and Toxicology 35: 354-367.

Olsen, B. R., Reginato, A. M. \& Wang, W. 2000: Bone development. - Annual Review of Cell and Developmental Biology 16: 191-220.

Olsson, M. \& Reutergårdh, L. 1986: DDT and PCB pollution trends in the Swedish aquatic environment. - Ambio 15: 103-109.

Palmer, A. R. 1994: Fluctuating asymmetry analyses: a primer. - In: Markow, T. A. (ed.), Developmental instability: its origins and evolutionary implications: 335364. Kluwer, Dordrecht.

Palmer, A. R. \& Strobeck, C. 2003a: Fluctuating asymmetry analyses revisited. - In: Polak, M. (ed.), Developmental instability. Causes and consequences: 279-319. Oxford University Press, Oxford.

Palmer, A. R. \& Strobeck, C. 2003b: Fluctuating asymmetry analysis: a step-by-step example [Electronic Appendix V in: Fluctuating asymmetry analyses revisited]. - In: Polak, M. (ed.), Developmental instability. Causes and consequences: 279-319. Oxford University Press, Oxford.

Pelabon, C., Hansen, T. F., Carlson, M. L. \& Armbruster, W. S. 2006: Patterns of asymmetry in the twining vine Dalechampia scandens (Euphorbiaceae): Ontogenetic and hierarchical perspectives. - New Phytologist 170: 65-74.

Pertoldi, C., Podestá, M., Loeschcke, V., Schandorff, S., Marsili, L., Mancusi, C., Nicolosi, P. \& Randi, E. 2000b: Effect of the 1990 die-off in the northern Italian seas on the developmental stability of the striped dolphin Stenella coeruleoalba (Meyen, 1833). - Biological Journal of the Linnean Society 71: 61-70.

Pertoldi, C., Bach, L. A., Barker, J. S. F., Lundberg, P. \& Loeschcke, V. 2007: The consequences of the variance-mean rescaling effect on effective population size. - Oikos 116: 769-774.

Pertoldi, C., Bach, L. A., Madsen, A. B., Randi, E. \& Loeschcke, V. 2003: Morphological variability and developmental instability in subpopulations of the Eurasian badger (Meles meles) in Denmark. - Journal of Biogeography 30: 949-958.

Pertoldi, C., Loeschcke, V., Braun, A., Madsen, A. B. \& Randi, E. 2000a: Craniometrical variability and developmental stability. Two useful tools for assessing the population viability of Eurasian otter (Lutra lutra) populations in Europe. - Biological Journal of the Linnean Society 70: 309-323.

Pertoldi, C., Loeschcke, V., Madsen, A. B. \& Randi, E. 1997: Developmental stability in the Eurasian Otter (Lutra lutra) in Denmark. - Annales Zoologici Fennici 34: 187-196. 
Petavy, G., David, J. R., Debat, V., Pertoldi, C. \& Moreteau, B. 2006: Phenotypic and genetic variability of sternopleural bristle number in Drosophila melanogaster under thermal stress: developmental instability and anti-symmetry. - Evolutionary Ecology Research 8(1): 149-167.

Polischuk, S. C., Norstrom, R. J. \& Ramsay, M. A. 2002: Body burdens and tissue concentrations of organochlorines in polar bears (Ursus maritimus) vary during seasonal fasts. - Environmental Pollution 118: 29-39.

Pravosudov, V. V. \& Kitaysky, A. S. 2006: Effects of nutritional restrictions during post-hatching development on adrenocortical function in western scrub-jays (Aphelocoma californica). - General and Comparative Endocrinology 145(1): 25-31.

Prince, M. E. \& Silva, M. 2002: On the determinants of census area: implications for mammalian macroecological patterns. - Global Ecology \& Biogeography 11: 401-409.

Ramsay, M. A. \& Stirling, I. 1988: Reproductive biology and ecology of female polar bears (Ursus maritimus). - Journal of Zoology 214: 601-634.

Regehr, E. V., Lunn, N. J., Amstrup, S. C. \& Stirling, I. 2005: Population decline of polar bears in Western Hudson Bay in relation to climatic warming. - In: 16th Biennial Conference on Marine Mammals, San Diego, California, December 12th-16th, 2005: 233-234. Society for Marine Mammalogy.

Riget, F. 2005: Tidsmæssig udvikling af kontaminanter i grønlandske dyr - en statusrapport. Arbejdsrapport fra DMU (Danmarks Miljфunders $\phi$ gelser), Nr. 228.

Rosing-Asvid, A., Born, E. W. \& Kingsley, M. C. S. 2002: Age at sexual maturity of males and timing of the mating season of polar bears (Ursus maritimus) in Greenland. - Polar Biology 25(12): 878-883.

Sandala, G. M., Sonne-Hansen, C., Dietz, R., Muir, D. C. G., Valters, K., Bennett, E. R., Born, E. W. \& Letcher, R. J. 2004: Hydroxylated and methyl sulfone PCB metabolites in adipose and whole blood of polar bear (Ursus maritimus) from East Greenland. - Science of the Total Environment 331: 125-141.

Schandorff, S. 1997: Developmental stability and skull lesions in the harbour seal (Phoca vitulina) in the 19th and 20th centuries. - Annales Zoologici Fennici 34: 151-166.

Siegel, M. I. \& Mooney, M. P. 1987: Perinatal stress and increased fluctuating asymmetry of dental calcium in the laboratory rat. - American Journal of Physical Anthropology 73: 267-270.

Siegel, M. I., Doyle, W. J. \& Kelley, C. 1977a: Heat stress, fluctuating asymmetry and prenatal selection in the laboratory rat. - American Journal of Physical Anthropology 46: 121-126.

Siegel, P., Siegel, M. I., Krimmer, E. C., Doyle, W. J. \& Barry, H. III 1977b: Fluctuating dental asymmetry as an indicator of the stressful prenatal effects of $\Delta^{9}$-tetrahydrocannabinol in the laboratory rat. - Toxicology and applied pharmacology 42: 339-344.

Skaare, J. U., Bernhoft, A., Derocher, A. E., Gabrielsen, G. W., Goksøyr, A., Henriksen, E., Larsen, H. J., Lie, E. \&
Wiig, Ø. 2000: Organochlorines in top predators at Svalbard - occurrence, levels and effects. - Toxicology Letters 112-113: 103-109.

Smithwick, M., Norstrom, R. J., Mabury, S. A., Solomon, K., Evans, T. J., Stirling, I., Taylor, M. K. \& Muir, D. C. G. 2006: Temporal trends of perfluoroalkyl contaminants in polar bears (Ursus maritimus) from two locations in the North American Arctic, 1972-2002. - Environmental Science \& Technology 40: 1139-1143.

Sonne, C., Dietz, R., Leifsson, P. S., Born, E. W., Kirkegaard, M., Riget, F. F., Letcher, R., Muir, D. C. G. \& Hyldstrup, L. 2005b: Do organochlorine contaminants contribute to histopathology in liver from East Greenland polar bears (Ursus maritimus)? - Environmental Health Perspectives 113: 1569-1574.

Sonne, C., Dietz, R., Leifsson, P. S., Born, E. W., Kirkegaard, M., Letcher, R. J., Muir, D. C. G., Riget, F. F. \& Hyldstrup, L. 2006a: Are organohalogen contaminants a co-factor in the development of renal lesions in East Greenland polar bears (Ursus maritimus)? - Environmental Toxicology and Chemistry 25: 1551-1557.

Sonne, C., Leifsson, P. S., Dietz, R., Born, E. W., Letcher, R. J., Hyldstrup, L., Riget, F. F., Kirkegaard, M. \& Muir, D. C. G. 2006b: Xenoendocrine pollutants may reduce size of sexual organs in East Greenland polar bears (Ursus maritimus). - Environmental Science \& Technology 40: 5668-5674.

Sonne, C., Dietz, R., Born, E. W., Riget, F. F., Kirkegaard, M., Hyldstrup, L., Letcher, R. J. \& Muir, D. C. G. 2004: Is bone mineral composition disrupted by organochlorines in East Greenland polar bears (Ursus maritimus)? - Environmental Health Perspectives 112: 1711-1716.

Sonne, C., Riget, F. F., Dietz, R., Kirkegaard, M., Born, E. W., Letcher, R. \& Muir, D. C. G. 2005a: Trends in fluctuating asymmetry in East Greenland polar bears (Ursus maritimus) from 1892 to 2002 in relation to organohalogen pollution. - Science of the Total Environment 341: 81-96.

Sonne, C., Rigét, F. F., Dietz, R., Wiig, Ø., Kirkegaard, M. \& Born, E. W. 2007: Skull pathology in East Greenland and Svalbard polar bears (Ursus maritimus) during 1892 to 2002 in relation to organochlorine pollution. - Science of the Total Environment 372: 554-561.

Stige, L. C. 2004: Fluctuating asymmetry: a marker of individual genetic or phenotypic quality? - Ph.D. thesis, Department of Biology, University of Oslo.

Valetsky, A. V., Dmitrieva, I. L., Krushinskaya, N. L. \& Zakharov, V. M. 1997: Social stress impact on developmental stability of laboratory rat Rattus norvegicus. - Acta Theriologica Suppl. 4: 27-32.

Verreault, J., Muir, D. C. G., Norstrom, R. J., Stirling, I., Fisk, A. T., Gabrielsen, G. W., Derocher, A. E., Evans, T. J., Dietz, R., Sonne, C., Sandala, G. M., Gebbink, W., Riget, F. F., Born, E. W., Taylor, M. K., Nagy, J. \& Letcher, R. J. 2005: Chlorinated hydrocarbon contaminants and metabolites in polar bear (Ursus maritimus) from Alaska, Canada, East Greenland, and Svalbard: 1996-2002. - Science of the Total Environment 351352: 369-390.

Vieth, R., Ladak, Y. \& Walfish, P. G. 2003: Age-related 
changes in the 25-hydroxyvitamin D versus parathyroid hormone relationship suggest a different reason why older adults require more vitamin D. - The Journal of Clinical Endocrinology \& Metabolism 88: 185-191.

Vilisics, F., Solymos, P. \& Hornung, E. 2005: Measuring fluctuating asymmetry of the terrestrial isopod Trachelipus rathkii (Crustacea: Isopoda, Oniscidea). - European Journal of Soil Biology 41: 85-90.

Voigt, C. C., Heckel, G. \& Mayer, F. 2005: Sexual selection favours small and symmetric males in the polygynous greater sac-winged bat Saccopteryx bilineata (Emballonuridae, Chiroptera). - Behavioral Ecology and Sociobiology 57: 457-464.

Wiig, Ø. 2005: Are polar bears threatened? - Science 309: 1814-1815.

Wiig, Ø., Derocher, A. E., Cronin, M. M. \& Skaare, J. U.
1998: Female pseudohermaphrodite polar bears at Svalbard. - Journal of Wildlife Diseases 34: 792-796.

Zakharov, V. M. 1992: Population phenogenetics: Analysis of developmental stability in natural populations. - Acta Zoologica Fennica 191: 7-30.

Zakharov, V. M. \& Yablokov, A. V. 1990: Skull asymmetry in the Baltic grey seal: effects of environmental pollution. - Ambio 19: 266-269.

Zakharov, V. M., Valetsky, A. V. \& Yablokov, A. V. 1997a: Dynamics of developmental stability of seals and pollution in the Baltic Sea. - Acta Theriologica Suppl. 4: 9-16.

Zakharov, V. M., Demin, D. V., Baranov, A. S., Borisov, V. I., Valetsky, A. V. \& Sheftel, B. I. 1997b: Developmental stability and population dynamics of shrews Sorex in central Siberia. - Acta Theriologica Suppl. 4: 41-48. 